\title{
Learners' Preparedness for Digital Learning Materials as Supplement of Self-Learning Materials of Open School of Bangladesh Open University
}

\author{
Khan Ferdousour Rahman ${ }^{1, *}$, Sabina Yeasmin ${ }^{2}$ \\ ${ }^{1}$ State University of Bangladesh \\ ${ }^{2}$ Bangladesh Open University \\ *Corresponding Author: ferdous3820@yahoo.co.uk
}

Copyright (c) 2013 Horizon Research Publishing All rights reserved

\begin{abstract}
Despite the imperatives of policy and rhetoric about integration of Information and Communication Technologies (ICTs), the Open School of Bangladesh Open University often uses digital learning materials as an 'add-on' in few courses of programs. Current government's agenda of implementing 'Digital Bangladesh' provides a key to harnessing the educational potential of digital resources, Internet communications, virtual interactive classroom and interactive multimedia to engage the interest, interaction, and knowledge construction of disadvantaged learners of the Open School at Bangladesh Open University. To the extent that such approaches go beyond and transform traditional open schooling model. This paper investigates the changing requirements and new possibilities represented by the challenges of integrating ICTs in open school programs in a way which at the same time connects more effectively with both the specific contents of the curriculum and the various stages and elements of the learning process. Case studies from Open School of Bangladesh Open University courses provide an exemplary focus of inquiry in order to better link relevant new theories or models of learning with digital materials, to see learner's preparedness related learner-centered strategies for integrating ICTs resources and tools, and to incorporate interdependent functions of learning as information access, communication, and applied interactions. This study suggests that designers should provide "ICTs supported learning activity" keeping the preparedness of the learners so that it becomes effective.
\end{abstract}

Keywords Technology, Digital, Virtual, Curriculum

\section{Introduction}

\subsection{Background}

Self-Learning Materials (SLMs) keep the learners active and help to improve their cognitive skills. Programmed learning materials and learning modules are such materials that follow self-study approach. Ding (2002) states that the advent of technology provides opportunities for more interactive and flexible distance learning programme. Traditional print-based distance learning programmes have experienced face lifts and adaptations to the web. The Open School of Bangladesh Open University (BOU-OS) often uses digital learning materials (DLMs) as an 'add-on' in English course of Higher Secondary Certificate (HSC) programme. Open School plans to introduce more DLMs as the current government's agenda of implementing 'Digital Bangladesh' provides a key to harnessing the educational potential of digital resources such as Open Educational Resources (OER) and Massive Open Online Course

(MOOC), Internet communications, virtual interactive classroom (VIC) and interactive multimedia to engage the interest, interaction, and knowledge construction of disadvantaged learners of the BOU-OS. This extension activity transforms traditional open schooling model. This paper investigates the changing requirements and new possibilities represented by the challenge of integrating Information and Communication Technologies ( ICTs) in open school programmes in a way which at the same time connects more effectively with both the specific contents of the curriculum and the various stages and elements of the learning process. This study suggests that designers should provide 'ICT-supported learning activity' keeping the preparedness of the learners so that it becomes effective.

\subsection{Problem Statement}

Across the country, students are taking on roles that are pushing the traditional boundaries of learning. Through these opportunities, students can connect to their future with authentic and meaningful learning. The problem that the Open School confronts with is how the learners could enhance this learning activity with digital learning materials. 
The major handicap lies with no access of the learners in the computers of the Tutorial Centres (TCs). So it is not feasible to introduce teaching through digital means. The investigator, therefore, attempted to test the effectiveness of this approach using personal computer. Again few scholars claim that it is the time of blended learning, which brings together the best of classroom and online learning opportunities with ICTs in order to promote active, independent learning. Thus this has eventually become a major concern of scientific inquiry, in which it focuses on the pedagogical usability criteria for evaluating the DLMs and the preparedness of students to access study aids such as lecture recordings via traditional and digital devices.

\subsection{Objective}

The overall objective of this paper is to explore the feasibility of the implementation of DLMs for the Open School programmes. However, the specific objectives are as follows:

- To examine the key concepts, values and principles of DLMs;

- To investigate the scope of promoting awarement of the different dimensions of DLMs that need to be considered when establishing and maintaining a digital system in the BOU-OS; and

- To find out the solution of the problem.

\section{Literature Review}

Access to computer, mobile and electronic devices has increased drastically in Bangladesh; but it has poor access to broadband Internet connectivity particularly in the rural area (Karim, 2008). Rahman \& Panda (2008) states that BOU Open School successfully prepared the virtual interactive classroom thorough TV program coupled with the mobile technology and its prospect is tremendous in the operation of the open schooling. John et al (2002) had found distance learning to be effective in increasing personnel' s readiness and also marked it as complementary to the conventional learning process. Phil (1989) advocated for more of audio visual tools for distance learning but did not negate the requirement of the printed materials. Joan (1989) emphasized on the use of micro computers for the same purpose. On the other hand, contemporary researchers (Edward 1996, Yun and JCurtis 2007) put more reliance on web based synchronous distance learning environment through video conferencing and other interactive ICT means. Now question arises that in what way does blended impact on our learning?

\section{Methods and Procedures}

The material serving as a basis for this research is drawn from a comprehensive survey carried out during field work between July and September 2013 in Bangladesh. This is basically a cross-sectional study using both qualitative and quantitative techniques. Sample size and sampling technique were sought out using conventional formula and method; and empirical data were collected from the targetted respondents. Structured questionnaires were used to have the opinion of the learners and interviews were made through mobile phones and face to face (f2f) contact. Besides the mobile phone access, the researcher was also able to communicate with the faculty members of the different courses within the Open School. Learners' mobile number was gathered from the Students Support Services (SSS) of BOU. The combination of qualitative and quantitative data served as a triangulation of data and enabled to use multiple methods. The qualitative approaches enabled the researcher to examine more closely people's interpretations and experiences of open learning. On the other hand, quantitative data helped to verify and supplement the findings obtained through the qualitative approaches. This study used mainly primary data, but some secondary data also served to support the empirical findings.

\section{Results and Discussion}

\subsection{General}

The BOU-OS is legally of equal status to the five other Schools (Faculties) of the University (Ministry of Law, 1992) namely School of Education (SoE), School of Business (SoB), School of Agriculture \& Rural Development (SARD), School of Science \& Technology (SST) and School of Social Sciences, Humanities \& Languages (SSHL). It offers three programmes named Junior School Certificate (JSC) for Grade: 6-8, Secondary School Certificate (SSC) for Grade: 9-10 and Higher Secondary Certificate (HSC) for Grade: 11-12. Established in 1992, the BOU has been the only Open and Distance Learning (ODL) provider in the country by law; and with the main campus in Gazipur, some $30 \mathrm{~km}$ north of the capital, Dhaka. The University enrolls each year nearly 100,000 learners in its 23 programmes of study and almost 90 percent of them are the learners of the Open School programmes. As such, Open School's programmes cover every remote corners of the country, and provide the highest revenue to the university exchequer.

Open School extensively uses print, radio-TV broadcasts at the national chunk and tutorial supports services near to the learners place. The program curriculum is at par to the conventional curriculum; not only that, this is the policy of BOU and that's why the Open School changes the syllabus of the courses when there is a change in the National Textbook and Curriculum Board (NCTB). SSC and HSC curriculum do not have vocational courses; but only the JSC Programme curriculum is coupled with the vocational courses and ICT learning materials, in a limited range, are used at the ODL centres. 


\subsection{Central Concepts}

Self Learning Material: SLMs refer to teaching materials that can be used by the learners without the assistance of teacher. These materials are designed for both on site and at distance learners to use on their own. These include all the material prepared to stimulate independent study/learning. The learners in distance education have less contact with either the institution or the tutor, and depend heavily on these especially prepared teaching materials - largely preplanned, pre-produced and pre-packed.

Digital Learning Material: DLM means all material that is designed for educational purposes, published in a digital form and intended to be accessed by computer.

Open Educational Resources: OER are materials used to support education that may be freely accessed, reused, modified, and shared by anyone. OER is now viewed as a natural way to implement distance learning, open education and new pedagogical approaches

Massive Open Online Course: MOOCs are defined by three elements - openness, being online and providing courses. Their openness means that they are available to anyone who wants to use them to learn. This logically implies that they are free, removing any financial barrier for even the poorest student. Being online means they are available on the internet. In providing courses, MOOCs represent a major shift in scale beyond open learning objects (Light, 2001). MOOCs provide great opportunities for non-traditional forms of teaching approaches and learner-centred pedagogy where students learn from one another. In fact $a$ it is designed to have large-scale participation - tens of thousands of students at no cost via an Internet connection and, upon completion, students may receive a 'verified certificate' of completion or college credit.

\subsection{Learning Everywhere: ICT-enabled Learning Support}

Digital learning not only takes place online or in the university classroom but is also situated in high schools, museums, after school programs, home schoolers' living rooms, public libraries, and peer-to-peer universities. Learners do not learn exclusively in the university where 'master-teachers' impart their insights under the tree of knowledge. Due to ICT revolution, now we find a paradigm shift of using digital contents instead of SLMs. Digital technology provides new opportunities for rich reuses of content in many educational contexts, from the traditional classroom to the cutting-edge openness. A digital learning and training environment consists of the content of the program offered, the learning context (location), the degree of self-guidance and the role of the mentor.

The government is implementing the Digital-Bangladesh agenda and its impact on the BOU system is tremendous. Therefore, Open School plans for digital content development so that it can be used for the learners as ICT-enabled learners' supports. In this survey, mean value of the learners responses on study materials reflect the ICT aspects is 3.95; this provides that learners of the Open School are prepared to have the ICT enabled leaning supports.

\subsection{Radio and TV Broadcasts}

BOU obtained allocation of airtime on national radio and television. The programme direct costs are quite modest because the University does not pay any broadcasting fee. This chunk is allocated to each School each week regardless of how many students or how many programmes each school has. The Open School broadcasts TV programme to courses that would most benefit from access to this facilities. The TV programme is very popular to the learners as the mean value is 3.53. In addition, learners like TV programme with compare to attend the tutorial classes (mean value is 4.54 ).

\subsection{Virtual Interactive Classroom}

The BOU-OS runs VIC programme to make a video interactive for the English course of the HSC program of the School. This approach is new at the Open School although it runs TV broadcast on the national television named Bangladesh Television (BTV) since its inception in 1993. The method uses mobile technology as the interactivity tool and BOU enters into the m-learning through this methodology. At the moment, about 99 percent area of the country is under mobile network. About 30 percent households use TV and 50 percent use mobile phone. Given the situation, BOU has tremendous opportunity for making interactive videos for its different programmes which may change the learning activity of the open school learners. Open School has a plan for increase this interactivity video for other courses particularly urban based learners who, sometimes, live in highly remote area. Open School learners have the mobile phones and they contact with tutors (mean value is 3.51). This means there is a tremendous prospect of VIC within the School and learners are prepared to have this opportunity of learning resources. 
Table 1. Learners' Responses on ICT Materials

\begin{tabular}{|c|c|c|c|c|c|c|c|}
\hline \multirow{2}{*}{\multicolumn{2}{|c|}{ Criteria Statement }} & \multicolumn{5}{|c|}{ Percentages of learners' opinion } & \multirow{3}{*}{$\begin{array}{c}\begin{array}{c}\text { Mean } \\
\text { Responses }\end{array} \\
4.00\end{array}$} \\
\hline & & \multirow{2}{*}{$\begin{array}{c}\text { Strongly } \\
\text { Disagree }\end{array}$} & \multirow{2}{*}{$\begin{array}{c}\text { Disagree } \\
4.3\end{array}$} & \multirow{2}{*}{$\begin{array}{c}\text { Undecided } \\
13.8\end{array}$} & \multirow{2}{*}{$\begin{array}{c}\text { Agree } \\
46.8\end{array}$} & \multirow{2}{*}{$\begin{array}{c}\begin{array}{c}\text { Strongly } \\
\text { Agree }\end{array} \\
31.9\end{array}$} & \\
\hline n94 & Textbooks encouraged learning & & & & & & \\
\hline $\mathrm{n} 88$ & Too much content in the texts & 21.6 & 29.5 & 21.6 & 13.6 & 13.6 & 2.68 \\
\hline n94 & $\begin{array}{c}\text { Use of learning CDs in addition } \\
\text { to BOU text }\end{array}$ & 20.2 & 42.6 & 16.0 & 12.8 & 8.5 & 2.47 \\
\hline n90 & ICT is useful for difficult content & 28.9 & 38.9 & 16.7 & 7.8 & 7.8 & 2.27 \\
\hline n94 & $\begin{array}{l}\text { Use of mobile to communicate } \\
\text { with tutors }\end{array}$ & 5.3 & 25.5 & 9.6 & 31.9 & 27.7 & 3.51 \\
\hline n93 & Use of TV program & 7.5 & 20.4 & 10.8 & 34.4 & 26.9 & 3.53 \\
\hline n94 & $\begin{array}{l}\text { Desire for texts are supported } \\
\text { with video clips }\end{array}$ & 20.2 & 37.2 & 16.0 & 21.3 & 5.3 & 2.54 \\
\hline n94 & $\begin{array}{c}\text { Desire interactive video as } \\
\text { learning materials }\end{array}$ & 14.9 & 40.4 & 10.6 & 22.3 & 11.7 & 2.76 \\
\hline n96 & Internet connection at home & 15.6 & 51.6 & 15.6 & 12.5 & 1 & 2.60 \\
\hline n92 & Regular use of cyber café & 7.6 & 23.9 & 12.0 & 35.9 & 20.7 & 3.38 \\
\hline $\mathrm{n} 90$ & $\begin{array}{l}\text { Friend's Internet connectivity } \\
\text { group study }\end{array}$ & 5.6 & 21.1 & 7.8 & 43.3 & 22.2 & 3.56 \\
\hline n95 & $\begin{array}{l}\text { Needed ICT materials to } \\
\text { understand the content }\end{array}$ & 1.1 & 14.7 & 9.5 & 53.7 & 21.1 & 3.79 \\
\hline $\mathrm{n} 90$ & $\begin{array}{l}\text { TV-programs more interesting } \\
\text { than real life classroom at the } \\
\text { tutorial centre }\end{array}$ & 0 & 24.4 & 7.8 & 53.3 & 12.2 & 4.54 \\
\hline $\mathrm{n} 88$ & $\begin{array}{l}\text { Believe that I would if my study } \\
\text { materials reflect the ICT aspects }\end{array}$ & 1.1 & 8.0 & 6.8 & 62.5 & 21.6 & 3.95 \\
\hline
\end{tabular}

Source: Fieldwork, 2013

\subsection{Process for Digital Lesson Notes}

The Open School aims to develop e-content by the Course Lecturer in the form of the lesson notes and to publish in the BOU website after a review by the Assessor, who is authorized by the relevant academic unit and appointed by the BOU Authority. A reviewer is responsible for making an assessment of the overall structure, balance), and teaching points; and reporting formally in writing to the Dean of the Open School.

\subsection{Usefulness of Digital Lesson Notes}

Past experience says that Open School always delayed in delivery of the texts to the learners and tutors were experienced in conducting tutorials because of non-availablity of the books. It is expected that these online lesson notes will eliminate this problem because most of the TCs already been equipped with the computer due to the implemention of the Digital Bangladesh agenda. Ministry of Education directed BOU to communicate with Ministry via email only and this order has established availability of the Internet in the TCs. Therefore, all the learners of the Open School have the Internet access and they can get print of the lesson notes. In addition, 99 percent area of Bangladesh is now under mobile network; and Internet is available all over the country. So the learners can get the tutorial notes either in the centre or in the cyber café, which are available in any business centre near to the TCs. The learners' mean response on use of cyber café is 3.38 . This means digital content plan by Open School may be successful as the learners are going to cyber café as they don't have their own Internet connection (mean value is 2.60); but they can have this facility from the friends (mean value is 3.56). Therefore, Open School plans for digital content development so that it can be useful for the learners as ICT-enabled learners' support.

\section{Conclusion}

\subsection{Preparedness for Flexible Access to Learning Materials: How Ready are We?}

ICTs provide new opportunities for learning and teaching. However, for students to benefit from these opportunities, they must have ready access to ICT and positive attitudes toward its usefulness for learning.

It is also apparent that most students are prepared to access learning materials from the Web and have convenient access to Internet connected computer systems that are adequate for the purposes of study. However, many students have limited or no access to devices that would support mobile access to study materials such as recorded lectures or websites and many have little or no experience of such ICT. Given their general lack of confidence about solving technical problems, more widespread use of mobile devices to access study materials will require careful attention to ensuring that 
systems are as user-friendly as possible and are accompanied by support materials that promote the advantages and assist students with avoiding the pitfalls that may be associated with new ICT.

Digital media can help learners to become more active participants in public life and, moreover, can facilitate subversive, radical pedagogy and civic engagement. This also means that we need to stop ignoring the ways in which we teach behind closed doors and radically focus on media pedagogy as an urgent topic on which we should work together.

\subsection{Concluding Remarks}

The data presented in this paper confirm that students are attitudinally prepared for the use of ICT in their studies. They regard ICT as having potential to make study more convenient and improve their results while developing skills that enhance their career prospects. They are generally confident that they have the skills necessary for routine access to familiar forms of ICT but their lack of confidence in their abilities to solve their own technical problems is likely to contribute to a preference for staying with familiar ICT rather than exploring new opportunities.

Going digital is very dynamic step of the BOU-OS and it is also a big challenge for the University as a whole. This attempt will advance the School activities and will generate a digital learning environment for the learner's confidence to compete in the digital world. Digital vision has turned Bangladesh education system into introducing the e-education. Therefore, the Open School has been the one of the contributors in achieving this goal. Learners are also prepared to cope with the digital decision of the School. The SLMs prepared for the learners are very handsome to them as well they demands for the DLMs to complete their learning.

\section{REFERENCES}

[1] Chen, Y-J. and Willits, F. K. 1999, Dimensions of educational transactions in a videoconferencing learning environment, The American Journal of Distance Education, 13(1), 45-59.
[2] Ding, X. 2002, Distance higher education in the digital era, Plenary Address at the 16th AAOU Annual Conference, Seoul, November 5-7.

[3] Edward, Spodick F. 1996, The Evolution of Distance Learning, Hong Kong University of Science \& Technology.

[4] Joan, Fulton R. 1989, Microcomputers in Distance Education, University of Alberta, Edmonton, Canada.

[5] John, Winkler D.; Henry, Leonard A. and Michael, Shanley G. 2002, Army Distance Learning: Potentials for Reducing Shortage in Army Enlisted Occupations, RAND Arroyo Center.

[6] Light, R. 2001, Making the most of college: Students speak their minds, Harvard University Press.

[7] McDonald, J. and Gibson, C. C. 1998, Interpersonal dynamics and group development in computer conferencing, The American Journal of Distance Education, 12(1), 7-25.

[8] Phil, Race 1989, The Open Learning Handbook: Selecting Designing and Supporting Open Learning Materials, New York: Nichols Publishing.

[9] Rahman, M. M. and Panda, S. 2008, Study on Policy and Advocacy Initiatives of UNESCO for Promoting Low-Cost Media and Technology to Support Distance Education in Bangladesh, Report and Proceedings of 14th Annual Conference of Indian Distance Education (IDEA): IDEA 2008, 14th to 16th November 2008, Institute of Distance and Open Learning, Gauhati University, Assam, India.

[10] Open School 2009, Higher Secondary Certificate (HSC) Prospectus, Bangladesh Open University, Gazipur.

[11] Ministry of Education 2010, Secondary Circulars, Available at: http://www.moedu.gov.bd/index.php?option=com_content\& task= view\&id=407\&Itemid $=405$

[12] Karim, M. A. 2008, E-Learning \& M-Learning in Bangladesh: Hopeless state to Dreamworld! Available at: $\mathrm{http}: / /$ mskhalid.wordpress.com/e-learning-m-learning-in-ban gladesh-hopeless-state-to-dreamworld/

[13] Yun, Park Jeong and JCurtis, Bonk 2007, Synchronous Learning Experiences: Distance and Residential Learners' Perspectives in a Blended Graduate Course, Journal of Interactive Online Learning, 6(3). 